\title{
CARVING A FAIR DEAL TO SECURE RIGHT TO EDUCATION WITHIN COPYRIGHT FRAMEWORK
}

\author{
DESENVOLVENDO UM OBJETIVO JUSTO PARA GARANTIR O DIREITO À \\ EDUCAÇÃO NO QUADRO DOS DIREITOS AUTORAIS
}

Yashomati Gosh

Ph.D pela National Law School of India University Bangalore. Associate Professor, National Law School of India University Bangalore.

\section{Resumo}

Os direitos autorais visam promover o conhecimento e a conscientização da sociedade, fornecendo proteção legal às obras criativas e originais. Obras literárias, artísticas, musicais originais e outras formas de criação são reconhecidas como questões de esforço criativo que a lei visa proteger através da concessão de certos direitos econômicos e morais exclusivos aos detentores dos direitos autorais. Esses direitos, no entanto, não são absolutos e a lei de direitos autorais cria certas exceções com base nas necessidades da sociedade. Essas exceções foram designadas como "uso justo" ou "tratamento justo". Os direitos autorais devem ser analisados a partir do objetivo dos direitos humanos de garantir o direito à educação para a vasta maioria das pessoas comuns através das lentes das disposições de tratamento justo. A promoção da educação é uma meta de direitos humanos para todas as nações e é importante interpretar as disposições da lei de direitos autorais de uma maneira que cumpra esse objetivo.

Palavras-chave: Direitos Autorais; Direito à Educação; Direitos Humanos; Tratamento Justo.

\begin{abstract}
Copyright law aims to promote knowledge and awareness in society by providing legal protection to the creative and original works. Original literary, artistic, musical works and other forms of creations are recognised as matters creative endeavour which the law aims to
\end{abstract}


protect through grant of certain exclusive economic and moral rights to the copyright holders. But these rights are not absolute in nature and the copyright law creates certain exceptions based on the needs of the society. These exceptions have been labelled as 'fair use' or 'fair dealing'. In this paper the copyright law is analysed from the touchstone of securing the human right goal of securing right to education for the vast majority of the common people through the lenses of fair dealing provisions. Promotion of education is a human rights goal for all nations and it is important to interpret the provisions of copyright law in a manner which fulfils that goal.

Key-words: Copyright; Right to education; Human rights; Fair Dealing.

\section{INTRODUCTION}

Copyright law aims to promote knowledge and awareness in society by providing legal protection to the creative and original works. Original literary, artistic, musical works and other forms of creations are recognised as matters creative endeavour which the law aims to protect through grant of certain exclusive economic and moral rights to the copyright holders. The different rights granted to authors are right to reproduction, issuing copies of the work to the public, renting or lending the work to the public, performing, showing or playing the work in public, communicating the work to the public and making an adaptation of the work etc. But these rights are not absolute in nature and the copyright law creates certain exceptions based on the needs of the society. These exceptions have been labelled as 'fair use' or 'fair dealing' and are granted to the users of copyrighted for the progress of science, art and culture in society. The advancement in technology has ensured that access to copyrighted works becomes easy, cheap and convenient for the users, which will promote the goal of universalization of education.

In this paper the copyright law is analysed from the touchstone of securing the human right goal of securing right to education for the vast majority of the common people through the lenses of fair dealing provisions. Promotion of education is a human rights goal for all nations and it is important to interpret the provisions of copyright law in a manner which fulfils that goal.

\section{COPYRIGHT LAW AS A TOOL FOR PROMOTING KNOWLEDGE AND EDUCATION}

Revista de Direitos Fundamentais \& Democracia, Curitiba, v. 25, n. 3, p. 283-297, set./dez. 2020 
The origin of copyright law in modern discourse is linked to the invention of the printing press which facilitated mass scale reproduction of literary works in the early $17^{\text {th }}$ century. Invention of the movable type by Johannes Gutenberg in 1436 enabled the publication of large number of books and pamphlets. The first copyright law which was enacted in England was the Statute of Anne 1710 was an attempt to regulate unauthorised reproduction of works by technological means by granting the legal right of exclusive authorship. The law granted the authors the right to authorise printing, reprinting and publication of books for a limited period. The primary objective of copyright law was to encourage learning in society. The copyright law facilitated the growth of publication industry by securing economic and financial benefits to authors and publishers, which helped members of the society to access books and other reading materials.

At the global level it was deemed necessary to create an international convention for protection of literary and artistic work so that the works of various authors could be protected at the international level and readers across nations could access those works. Victor Hugo in 1878 founded the Association Litteraire et Artistiquelnternationalewhich facilitated the creation of the first international convention on copyright law known as the Berne Convention for the Protection of Literary and Artistic work and securing the economic and legal rights of the authors. ${ }^{1}$ The authors were granted the exclusive rights of authorization involving the right to translate, right to make adaptations and arrangements of the work, right to perform in public, right to recite, right to recite, right to communicate to the public, right to broadcast, right to make reproductions and right to use the work as a basis for an audiovisual work. ${ }^{2}$ But in light of the social welfare goals of copyright law the Convention recognised that certain exceptions to the reproduction rights can be granted as long as it does notconflict with a normal exploitation of the work and does not unreasonably prejudice the legitimate interests of the author. ${ }^{3}$ Similar rights and exceptions have been recognised in other international copyright conventions and countries. ${ }^{4}$

The Preamble of the Indian Constitution recognizes the obligation of creating an independent nation wherein all citizens are guaranteed liberty of thought, expression

${ }^{1}$ Berne Convention for theProtectionofLiteraryandArtistic Works (1886) [as revisedandamended in 1979]

2Summaryofthe Berne Convention for theProtectionofLiteraryandArtistic Works (1886), availableathttps://www.wipo.int/treaties/en/ip/berne/summary berne.htmlvisitedon 05.02.2020

$3 / d$. Article 9

4 TRIPS, WIPO Copyright Treaty, WIPO Performances andPhonogramsTreaty

Revista de Direitos Fundamentais \& Democracia, Curitiba, v. 25, n. 3, p. 283-297, set./dez. 2020 
and belief. Article 19 of the Constitution secures the fundamental right of all citizens to freedom of speech and expression and this freedom forms the basis of Copyright Act 1957. For the purpose of fulfilling these goals the Constitution has imposed duties on both state and the citizens 'to value and preserve the rich heritage of our composite culture' and 'to develop the scientific temper, humanism and the spirit of inquiry and reform' under the Fundamental Duties chapter. ${ }^{5}$ In the first landmark judicial decision on the application of copyright law the Supreme Court in R.G. Anand v. Delux Films ${ }^{6}$ recognized the labour-reward theory for justification of copyright protection -

\begin{abstract}
[T] he fundamental idea of violation of copyright or imitation is the violation of the Eighth Commandment: "Thou shall not steal" which forms the moral basis of the protective provisions of the Copyright Act of 1911. It is obvious that when a writer or a dramatist produces a drama it is a result of his great labour, energy, time and ability and if any other person is allowed to appropriate the labours of the copy-righted work, his act amounts to theft by depriving the original owner of the copy-right of the product of his labour.
\end{abstract}

Recognising the importance of copyright as mechanism to promote learning and progress in society the Supreme Court in the leading case of Eastern Book Company v. D. B. Modak'had observed that -

The copyright, protection finds its justification in fair play. When a person produces something with his skill and labour, it normally belongs to him and the other person would not be permitted to make a profit but of the skill and labour of the original author and it is for this reason the Copyright Act, 1957 gives to the authors certain exclusive rights in relation to the certain work referred in the Act. The object of the Act is to protect the author of the copy right work from na unlaw ful reproduction or exploitation of his work by others. Copyright is a right to stop others from exploiting the work with out the consent or assent of the owner of the copyright. A copyright Law presents a balance between the interests na drights of the author and that of the public in protecting the public domain, or to claim the copyright and protect it under the copyright statute. One of the key requirements is that of originality which contributes, and has a direct nexus, in maintaining the interests of the author as well as that of public in protecting the matters in' public domain. It is a well-accepted principle of copyright Law that there is no copyright in the facts per se, as the facts

\footnotetext{
${ }^{5}$ YashomatiGhosh, JurisprudentialAnalysisoftheRightsoftheUsers in Copyrighted Works, ManojKumarSinhaandVandanaMahalwar (eds), Copyright Law in the Digital World, Springer (2017) ${ }^{6}$ AIR 1978 SC 1613

72008 (1) SCC 1

Revista de Direitos Fundamentais \& Democracia, Curitiba, v. 25, n. 3, p. 283-297, set./dez. 2020
} 
are not created nor have they originated with the author of any work which embodies these facts. The issue of copyright is closely connected to that of commercial viability, and commercial consequences and 6

Inspite of the laudable objective of copyright law, one of the major challenges which society has faced is in balancing the duty to promote education and knowledge for all members of the society on one hand and ensuring that unauthorised access to copyrighted works are prevented in order to reward the authors on the other hand.

\section{RIGHT TO EDUCATION AS A HUMAN RIGHT}

The Universal Declaration of Human Rights (UDHR) 1948 has recognized the right to education as a core human right. $^{8}$ Every individual has a right to education. Education is essential for the proper development of all human faculties and enabling individuals with necessary skills to cope in life. Education also promotes tolerance and understanding among communities and nations, and also helps in maintaining peace and harmony in society. It is deemed necessary that education should be free and compulsory at the elementary and fundamental stages. At the higher education level education should be made affordable for the vast majority of the people and also equally accessible based on merit. Articles 13 and 14 of the International Covenant of Economic, Social and Cultural Rights has recognized the right to free, compulsory primary education for all, an obligation to develop secondary education accessible to all, on particular by the progressive introduction of free secondary education, as well as an obligation to develop equitable access to higher education.' There are several other international conventions like UNESCO Convention against Discrimination in Education 1960, Convention on the Elimination of All Forms of Discrimination Against Women 1981 and Convention on the Rights of Persons with Disabilities 2006 which has advocated for right to compulsory education in a free, fair and equitable manner. In addition regional human rights conventions like African Charter on Human and Peoples' Rights and European Convention on Human Rights has also recognized education as a human right and access to education as a fundamental entitlement without any discrimination.

Right to education is assessed based on the framework of $4 A s$ which was advocated by Katarina Tomasevski, former UN Special Rapporteur on the Right to

${ }^{8}$ UDHR Article 26 availableathttps://www.un.org/en/udhrbook/pdf/udhr booklet en web.pdfvisitedon 29.02.2020

Revista de Direitos Fundamentais \& Democracia, Curitiba, v. 25, n. 3, p. 283-297, set./dez. 2020 
Education. ${ }^{9}$ The 4 As are - Availability, Accessibility, Acceptability and Adaptability. It is the responsibility of the state to ensure that universal, free and compulsory education is made available to all by ensuring proper availability of books, educational materials and infrastructure.

In India right to education is recognized as an integral part of right to life under Article 21 of the Constitution. In Mohini Jain v. State of Karnataka ${ }^{10}$ the Supreme Court had observed that "right to life (Article 21) is a compendious expression with all those rights which the courts must enforce because they are basic to the dignified enjoyment of life and that the dignity of an individual cannot be assured unless it is accompanied by the right to education." Similarly in Unnikrishnan v. State of Andhra Pradesh ${ }^{11}$ the Court recognized that right to education is "implicit in and flows from the right to life guaranteed under Article 21." The $86^{\text {th }}$ Amendment to the Constitution has introduced Article $21 \mathrm{~A}$ whereby right to free and compulsory education from 6 to 14 years of age is made a Fundamental Right. Subsequently the Right to Education Act, 2009 was enacted to achieve the constitutional goal of quality education for all. Under the National Policy on Education, 1992 the goal of universalization of education has been advocated. It recognizes different processes to promote universalization of education such as institutional learning, open schools, distance education, digital education etc. so as to bring education closer to all sections of the society such as Scheduled Tribes, Scheduled Castes, backward classes, minorities, women, persons with disabilities etc. It is the responsibility of the State to provide quality education and create adequate infrastructural facilities, teacher training programmes, course curriculum development initiatives, skill development, access to quality teaching and educational materials etc.

Towards fulfilling the goals of universal education, one of the biggest impediments is to make easy availability of books and other teaching materials at a reasonable cost. Imparting of education is to a great extent dependant on access to books and reading materials which have been included in the course curriculum and are often copyrighted materials. Hence access to copyrighted materials at reasonable is major challenge in fulfilment of the right to education.

\section{RIGHT TO EDUCATION VIS A VIS COPYRIGHT LAW}

\footnotetext{
${ }^{9}$ United NationsHumanRights,

SpecialRapporteuronthetoRighttoEducation, availableathttps://www.ohchr.org/EN/Issues/Education/SREducation/Pages/SREducationIndex.aspxvi sitedon 29.02.2020

10 (1992) 3 SCC 666

11 (1993) 1 SCC 645

Revista de Direitos Fundamentais \& Democracia, Curitiba, v. 25, n. 3, p. 283-297, set./dez. 2020
} 
According to World Bank India's per capita income is barely $\$ 2010$ per year (2018). ${ }^{12}$ In a developing country where the average income is low it is not possible for a common man to save any substantial amount on educational materials, after bearing his other living and housing expenditures. In such circumstances provide quality based on the 4 As become the responsibility of the state and people have to depend upon various reprographic techniques like scanning, printing, photocopying etc. to access quality educational materials ${ }^{13}$. Purchase of text books and reference materials are prohibitively expensive for many, particularly books written by foreign scholars and published by international publishers. Access to articles from referred journals which are part of major databases like Heinonline, Jstor etc. is possible only when there are institutional memberships on paying exorbitant annual charges. Non-access to high speed internet connection is also a factor which compels students and researchers to use reprographic techniques to read the materials. The use of reprography to access educational materials is often considered as unauthorised access to copyrighted materials because no license or authorisation is obtained from the copyright holder. Under Section 14 of ICA the term 'copyright' has been defined as the exclusive right to do or authorise the doing of acts such as "to reproduce the work in any material form including the storing of it in any medium by electronic means" and if any person does anything contrary to the exclusive rights which has been conferred to the copyright owner without license or authorization will be deemed to have committed copyright infringement and thereby punishable under the statute. ${ }^{14}$

It has been a long standing debate between the two competing rights - right to access educational materials and right of the authors to enjoy copyright protection as factors which may inhibit the goals of universalization of education. Just like right to education is a fundamental human right ${ }^{15}$, UDHR also recognises rights of the authors under Article 27 (2) of the Declaration - "Everyone has the right to the protection of the moral and material interests resulting from any scientific, literary or artistic production of which he is the author." The debate is further aggravated with the demands of the publishing

\footnotetext{
12World Bank, GDP PerCapita - India, availablehttps://data.worldbank.org/indicator/NY.GDP.PCAP.CD?locations=IN visited on 29-02-2020

13Indian Copyright Act (ICA) 1957 - Sec 2(x) 'reprography' meansthemakingof copies of a work, byphotocopyingor similar means.

The term reprography refers to the process of making copies or photocopies by various technological means like Xerox, microfilms, scanning, digital copies, computer printouts etc.

14 ICA Section 51

15 UDHR Article 26
}

Revista de Direitos Fundamentais \& Democracia, Curitiba, v. 25, n. 3, p. 283-297, set./dez. 2020 
industry who claims the need to ensure exclusive and higher standards of copyright protection in the era of digitization so as to prevent use of advanced forms of reprography in the spread of academic and educational materials. ${ }^{16}$

\section{INTERNATIONAL EFFORT TO BALANCE THE COMPETING LEGAL RIGHTS}

There is a conscious realization among the global community that exclusive grant of right of reproduction to the authors and publishers under the copyright regime and the ability to control the price grant of access is often a detriment for the vast majority of the people who are residing in the developing countries to pursue their education and often unable to bear the highly expensive textbooks and reference materials. The UDHR along with the right to education had also recognised the right of every individual to "freely participate in the cultural life of the community, to enjoy the arts and to share in scientific advancement and its benefits." 17 In light of this the international copyright regime has attempted to fulfil the social welfare goals of copyright law by advocating for certain limitations to the exclusive rights granted to the copyright holders in the form of fair use and fair dealing.

Various international copyright conventions have permitted the use of copyrighted work for educational purposes such as teaching, research, private study etc. Article 9 of the Berne Convention for the Protection of Literary and Artistic Works has allowed countries to make exceptions to the exclusive right of reproduction of the authors by providing that 'such reproduction does not conflict with a normal exploitation of the work and does not unreasonably prejudice the legitimate interests of the author.'18 The convention has provided for specific exceptions for the purpose of teaching. ${ }^{19}$

Recognising the importance of reprography practices in promoting education the Intergovernmental Copyright Committee organized by UNESCO had recommended in 1968 that reproduction for personal use, by non-commercial libraries and for educational purposes without payment of royalties should be permitted. ${ }^{20}$ The WIPO

\footnotetext{
${ }^{16}$ Universityof Oxford v. RameshwariPhotocopy Services 2016 SCC OnLine Del 6229

17 UDHR Article 27(1)

18 The copyright exceptionclauseisdescribed as 'three-steptest'.

${ }^{19}$ Berne ConventionArticle 10(2)

20UNESCO Doc 7C/23, Report of desirability of International Regulation Concerning the photographic Revista de Direitos Fundamentais \& Democracia, Curitiba, v. 25, n. 3, p. 283-297, set./dez. 2020
} 
Working Group in 1973 had also recommended "the personal use, use by instructors in educational institutions for teaching purposes, use for a library, were free uses especially for developing countries as they were not to pay remuneration in such cases and they were left to adjust their regulations relating to reprography according to their needs". ${ }^{21}$ The scope of reprographic reproductions was extended to any system or technique by which facsimile reproductions could be made, irrespective of their size or form. ${ }^{22}$ Keeping in consideration the needs of the developing countries the reproduction right was recognized for the first time in the Stockholm Act, 1967, after the Stockholm Conference. $^{23}$ The Act enabled national legislations to include provisions relating to limitation and exceptions to reproduction right. Similar exception clauses have been recognised under the TRIPS, which has incorporated the fundamental provisions of the Berne Convention and the WIPO Copyright Treaty dealing with the application of copyright law in the digital environment ${ }^{24}$. The international copyright conventions had acknowledged the use of excerpts in published works for educational and scientific purposes and had allowed individual member countries to determine its scope through domestic legislations.

\section{RIGHT TO EDUCATION EXCEPTION WITHIN THE INDIAN COPYRIGHT LAW}

The Copyright has played an important role in fulfilling the constitutional of creating a society where individuals can freely express themselves and contribute to the growth scientific development and culturally rich society. Section 52 of the Copyright Act has identified certain usages as outside the scope of copyright law and these these limitations on the scope of copyright protection is necessary to promote free speech, liberty of thought and expression and encourage the development of intellectual and creative thinking in men and women. ${ }^{25}$ Section 52 has granted certain legal rights to the

reproduction of copyright works

${ }^{21}$ WIPO Working Group on Reprographic Reproduction of works Protected by Copyright, 1973, Doc.. UNESCO/WIPO/R.P. 2/6 (21 Sept. 1973), Annex A

22 Id. Para 7.

23PoonamDass, ReproductionRight in Digital MediumandFree Use for EducationalPurpose AnanalysisofNationalandInternationalObligationsofIndiatoprovideEducationtoAllViz a vizProtecting Copyright, Copyright Law in the Digital World, Manoj Kr. SinhaandVandanaMahalwar (Ed.) Springer 2017

24 WIPO Copyright TreatyArticle 10 dealswithLimitationsandExceptions

${ }^{25}$ YashomatiGhosh, JurisprudentialAnalysisoftheRightsoftheUsers in Copyrighted Works, ManojKumarSinhaandVandanaMahalwar (eds), Copyright Law in the Digital World, Springer (2017) Revista de Direitos Fundamentais \& Democracia, Curitiba, v. 25, n. 3, p. 283-297, set./dez. 2020 
users of copyrighted works to use the works for certain specified purposes without being considered to have committed copyright infringement. ${ }^{26}$ The opening wordings of Section 52 - "The following acts shall not constitute an infringement of copyright, namely..." clearly indicates that the specified usages are not to be considered as exceptions to copyright but will be deemed to be outside the scope of copyright infringement under Section 51.

Specific fair dealings provisions relating to promotion of education are -

i. Fair dealing with any work for the purposes of private use, including research, criticism, review, whether of that work or of any other work. ${ }^{27}$

ii. Publication by a publisher for the purpose of use by educational institutions in a collection which is mainly composed of non-copyrighted materials, of short passages from published literary or dramatic works, which are copyrighted works but were not originally published for the use of educational institutions. ${ }^{28}$

iii. Reproduction of a copyrighted work by a teacher or a pupil in the course of instruction, as part of examination questions and as answers to such questions. ${ }^{29}$

iv. Performance of a copyrighted work in the course of the activities of an educational institution where the participants and audience are largely staffs and students of the educational institutions, and their parents and guardians. ${ }^{30}$

During the Parliamentary debate relating to the 2012 Copyright Amendment emphasising the importance of Section 52 in promoting research and education it was stated that "if a student wants to do research in copyrighted material he cannot be charged; if somebody wants to do research in copyrighted material, he cannot be charged; if somebody wants to teach copyrighted material, he cannot be charged." 31

In the leading case of Academy of General Education, Manipal v. $B$. MaliniMallya ${ }^{32}$ Supreme Court had analysed the application of fair dealing provisions in Section 52 for the purpose of use of copyrighted works in educational institutions. It categorically held that when a fair dealing is made of a literary or dramatic work for the private use including research and criticism or review, no copyright infringement can be claimed.

Section 52 of the Act provides for certain acts which would not constitute na

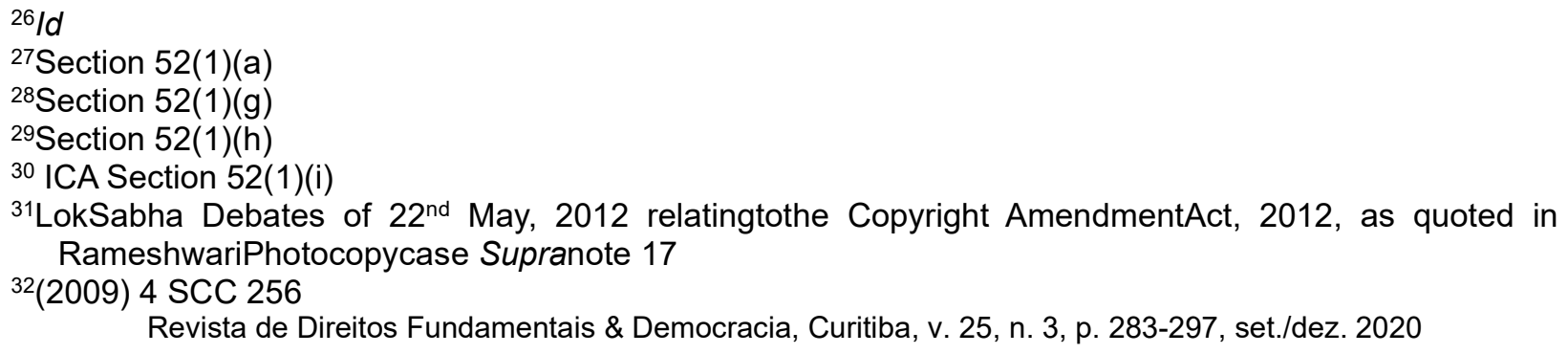




\begin{abstract}
in fringement of copyright. When a fair dealing is made, inter alia, of a literary or dramatic work for the purpose of private use including research and critic is mor review, whetherofthatworkorofanyotherwork, theright in termsoftheprovisionsofthesaidActcannotbeclaimed. Thus, if some performance or dance iscarried out withinthepurviewofthesaidclause, theorderofinjunctionshallnotbeapplicable. appellantbeinganeducationalinstitution, ifthe dance isperformedwithinthemeaningofprovisionsofclause (i) ofSub-section (1) ofSection 52 oftheActstrictly, theorderofinjunctionshallnotapplytheretoalso. Yetagain, ifsuch performance isconductedbefore a nonpayingaudiencebytheappellant, whichisaninstitutionif it comes withinthepurviewofamateurcluborsociety, thesamewouldnotconstituteanyviolationofthesaidorderofinjunction. ${ }^{33}$
\end{abstract}

One of the most significance cases in recent years relating to copyright law and access to education is the case of University of Oxford v. Rameshwari Photocopy Services $^{34}$. The significant question to be determined is whether the act of reprography of educational materials be determined from the touch stone of copyright infringement and the application of the three-step fair use test or such acts are required to be deemed as entirely outside the scope of copyright law application. The plaintiffs were leading publishers of various textbooks and had filed copyright infringement action against Rameshwari Photocopy Services and Delhi University for unauthorised photocopying, reproduction and distribution of substantial extracts by copying and compiling into course packs/ anthologies of copyrighted works on a large scale basis and circulating them for sale in 2012. The liability of the Delhi University was 'institutionalised infringement' largely based on the acts of its students and faculty members who recommended and encouraged students to buy course packs instead of legitimate copies of the publications. In addition the University's library was issuing books for the purpose of photocopying. The Court largely agreed with the arguments of the defendants who claimed that the acts of photocopying and preparation of the course packs were educational in nature and was exempted as copyright infringements under Section 52 (1)(a) and (h) of the Copyright Act, 1957. Some of the relevant observations of the Court towards balancing the competing claims of rights of the authors and the rights of the user to learn and educate themselves under the copyright law have been quoted below -

Clarifying on the relationship fair dealings and copyright infringement based on the interpretation of Sections 51 and 52 the Court made the following observations - 
Section 51 prescribes that copyright is infringed inter alia when any person does anything exclusive right to do which has been conferred by the Act on the owner of copyright. It follows, if there is no exclusive right, there is no infringement. Section 52 lists the acts which do not constitute infringement. Thus, even if exclusive right to do something constitutes copyright, if it finds mention in Section 52, doing thereof will still not constitute infringement and the outcome thereof will not be infringing copy within the meaning of Section $2(\mathrm{~m}) \cdot{ }^{35}$

The Court linked the Clauses (h), (i) and (j) of Section 52 with the goals of access and promotion of education by observing that -

\begin{abstract}
The settled principle of interpretation of statutes is that the legislature is to be deemed to have used the language in the context of the prevailing laws and societal situations to which the legislation is intended. Education in the country though at one time pursued in Guru-Shishyaparampara(Teacher disciple tradition) has for long now been institutionalised, both at school and post - school level, with imparting of education by a teacher individually having no recognition. There is no reason to interpret Section 52(1)(i) as providing for an individual teacher and an individual pupil and which, neither at the time of inclusion thereof in the statute nor now exists in the society. ${ }^{36}$
\end{abstract}

Interpreting the meaning of 'course of instruction' the court referred to several Indian and foreign judgments. Agreeing with the observations in Longman Group Ltd. $v$. Carrington Technical Institute Board of Governor ${ }^{37}$ wherein it was held that -

The ordinary meaning of the words "course of instruction" would include anything in the process of instruction with the process commencing at a time earlier than the time of instruction, at least for a teacher, and ending at a time later, at least for a student and that so long as the copying forms part of and arises out of the course of instruction, it would normally be in the course of instruction; it encompasses preparation of material to be used in the course of instruction.

The Court recognised the poor economic condition of the vast majority of the people and the need of the government to provide subsidized education and stated that Imparting of education by the defendant no. 2 University is heavily subsidized
with the students still being charged tuition fee only of Rs. 400 to $1,200 /-$ per
month. The students can never be expected to buy all the books, different
portions whereof are prescribed as suggested reading and can never be said
to be the potential customers of the plaintiffs. If the facility of photocopying
were to be not available, they would instead of sitting in the comforts of their
respective homes and reading from the photocopies would be spending long
hours in the library and making notes thereof. When modern technology is
available for comfort, it would be unfair to say that the students should not
avail thereof and continue to study as in ancient era. No law can be

${ }^{35}$ Id.at Para 29

${ }^{36}$ Id.at Para 55

37(1991) 2 NZLR 574

Revista de Direitos Fundamentais \& Democracia, Curitiba, v. 25, n. 3, p. 283-297, set./dez. 2020 
interpreted so as to result in any regression of the evolvement of the human being for the better. ${ }^{38}$

\title{
Acknowledging the presence of new forms of technology it observed -
}

Today, nearly all students of the defendant no.2 University would be carrying cell phones and most of the cell phones have a camera inbuilt which enables a student to, instead of taking notes from the books in the library, click photographs of each page of the portions of the book required to be studied by him and to thereafter by connecting the phone to the printer take print of the said photographs or to read directly from the cell phone or by connecting the same to a larger screen. The same would again qualify as fair use and which cannot be stopped. ${ }^{39}$

The Delhi High Court upheld that the photocopying for the purpose of creating education course packs falls within the bounds of educational exception as provided under Sec 52(1)(i) of the Indian Copyright Act as very few students would be able to buy the various reference books which are generally highly expensive.

\begin{abstract}
All that is happening in the present case is that instead of the defendant No.2 University issuing the book which may be sought after by a large number of students, to each one of them individually for limited period or limited hours and enabling each student to photocopy the passages or the contents thereof required by him -in the course of instructionll and thereby exposing the book to damage, the defendant No.2 University itself is supplying the said photocopies. It cannot be lost sight of that we are a country with a bulging population and where the pressure on all public resources and facilities is far beyond that in any other country or jurisdiction. While it may be possible for a student in a class of say 10 or 20 students to have the book issued from the library for a month and to laboriously take notes therefrom, the same is unworkable where the number of students run into hundreds if not thousands. According to me, what is permissible for a small number of students cannot be viewed differently, merely because the number of students is larger. Merely because instead of say 10 or 20 copies being made by students individually or by the librarian employed by the University, 100 or 1000 copies are being made, the same would not convert, what was not an infringement into an infringement. ${ }^{40}$
\end{abstract}

The judgment of Justice Rajiv S. Endlaw has been greatly appreciated as establishing a balance between the interests of the copyrights holders and the well being of the vast majority of the people. It recognises the importance of right to education and the need to provide easy access to educational materials. But it also emphasised the need to test each instance of reprography from the touchstone of being done in the course of educational instruction. Ultimately the leading publishers OUP,

\footnotetext{
${ }^{38} / d$.at Para 87

39 /d.at Para 78

40 Para 89
}

Revista de Direitos Fundamentais \& Democracia, Curitiba, v. 25, n. 3, p. 283-297, set./dez. 2020 
CUP and Taylor \& Francis withdrew the suit without appealing against the order of the Delhi High Court.

\section{CONCLUSION - NEED TO PROVIDE AFFORDABLE EDUCATION}

In a country like India, where large sections of the population live below the poverty line, the cost of education has been majorly subsidized by the state. At the school level the bulk of the responsibility is borne by the State in compliance with the 4As education by establishing and running government run schools in different parts of the country as well as supporting the cost of education for needy children under the Right of Children to Free and Compulsory Education Act. The government sponsors the entire cost of education in these schools by providing free books as well provides the students with healthy mid-day meals in order to make access to education attractive and affordable. At the higher education level, the government provides subsidized education to the students under different state sponsored universities. In the various central and state government universities the bulk of the educational costs such as tuition fee, salaries of the professors and staffs, infrastructure and library costs, canteen charges, hostel charges, mess charges etc are provided by the government, with the students required to pay only a nominal fee. In such circumstances it is contrary to public interest and the goals of universalization of education, if access to educational materials is made prohibitively expensive by making the cost of books and reading materials exorbitant. The primary goal of copyright law is to promote knowledge and learning in society and Indian Copyright Act has tried to ensure the same. Purchasing of original text books is not a reasonable option for many and in the absence of cheap reprography options would having to forgo reading of supplementary educational materials. The Rameshwari photocopy case is a landmark decision from a developing country perspective and lays down the jurisprudential premise towards a case for restricting the application of copyright law when it comes in conflict the right to education. The ultimate goal of copyright law is to promote knowledge in society and it is the responsibility of the different state functionaries, including the judiciary to adopt an approach which balances the needs of the users with the rights of the copyright holders. 
Recebido em 17/08/2020

Aprovado em 05/12/2020

Received in 17/08/2020

Approved in 05/12/2020 